\title{
Headache in Children: Update on Complementary Treatments
}

\author{
Stefanie Schetzek ${ }^{1} \quad$ Florian Heinen $^{1}$ Sigrid Kruse ${ }^{1} \quad$ Ingo Borggraefe $^{1} \quad$ Michaela Bonfert $^{1} \quad$ Charly Gaul $^{2}$ \\ Sven Gottschling ${ }^{3}$ Friedrich Ebinger ${ }^{4,5}$
}

\footnotetext{
1 Department of Paediatric Neurology and Developmental Medicine, Hauner Children's Hospital, University of Munich, Munich, Germany

2 Department of Neurology, University of Essen, Essen, Germany

${ }^{3}$ Centre for Palliative Care for Children, University Children's Hospital, Homburg, Germany

${ }^{4}$ Children's Hospital, Paderborn, Germany

${ }^{5}$ Center for Pediatrics, Department of Neuropediatrics, Ruprecht-

Karls-University of Heidelberg, Baden-Württemberg, Germany
}

Address for correspondence and reprint requests Stefanie Schetzek, MD, Department of Paediatric Neurology and Developmental Medicine, Hauner Children's Hospital, University of Munich, Lindwurmstrasse 4, 80337 Munich, Germany (e-mail: stefanie.schetzek@med.uni-muenchen.de).

Neuropediatrics 2013;44:25-33.

\begin{abstract}
Keywords

- children

- headache

- complementary and alternative medicine

Complementary and alternative medicine (CAM) is widely used by both physicians and patients with primary headache syndromes. Despite a considerable number of articles addressing CAM in primary headache syndromes, the overall evidence for CAM is still poor. The aim of this review was to give an overview of the current evidence of the main alternative therapies used in the treatment of primary headache syndromes of childhood. MEDLINE and Cochrane Library were systematically searched for articles dealing with complementary and alternative treatment or prophylaxis of headache and migraine published within the past 20 years.
\end{abstract}

\section{Introduction}

Complementary and alternative medicine (CAM) is increasingly popular in the treatment of headache in children. Several studies, performed in various countries, have shown a prevalence of the use of CAM among children with acute conditions of 12 to $23 \%^{1,2}$ and for children with chronic illnesses, 44 to $54 \%{ }^{3}$ Two German studies showed some use of CAM in $81.7 \%$ of the patients attending tertiary outpatient clinics $^{4}$ and that $75.7 \%$ of the 115 observed children in a pediatric day center received CAM from their parents. ${ }^{5}$ Most children in the day center $(58.4 \%)$ received a combination of CAM and so-called conventional medicine, whereas $15.6 \%$ used CAM alone and $26.0 \%$ used only conventional prescribed medications. The physician was informed about the CAM treatment only in half of the cases. ${ }^{5}$ Despite the growing number of publications on CAM, there is no generally accepted definition of CAM. ${ }^{6}$ The U.S. National Center for Complementary and Alternative Medicine defines CAM as "a group of diverse medical and health care systems, practices, and products that are not currently considered to be part of conventional medicine."7

The overall use of CAM therapies increased in the US population from 33.8 to $42.1 \%$ in the interval of 1990 to 1997 and in Germany from 52\% in 1970 to $65 \%$ in $1997 .{ }^{8,9}$ In general, pharmacologic prophylaxis of chronic headache in children is only indicated, if lifestyle modification and nonpharmacologic prophylaxis are not effective. ${ }^{10}$ The use of CAM is predominantly motivated by the wishes "to leave nothing undone," "to be active against the disease," and to avoid side effects. ${ }^{4}$ In both children and adults, the use of CAM in primary headache syndromes increases with a higher number of headache days, longer duration of headache treatment, higher personal costs, and use of CAM for other diseases. ${ }^{4}$ Studies addressing more established therapies than CAM in children deal with pharmacologic approaches to terminate acute headaches attacks and the prevention of received

October 3, 2012 accepted after revision

November 16, 2012

published online

January 11, 2013
Issue Theme Headaches in Childhood and Adolescence; Guest Editor, Florian Heinen, MD.
DOI http://dx.doi.org/ 10.1055/s-0032-1333435. ISSN 0174-304X. (c) 2013 Georg Thieme Verlag KC Stuttgart · New York 
attacks. ${ }^{10}$ This review gives an overview of the current evidence of the main alternative therapies used in the treatment of primary headache in children.

\section{Methods}

MEDLINE and Cochrane Library were systematically searched for articles dealing with complementary and alternative treatment or prophylaxis of headache/migraine published from September1992 through September 2012. To maximize the number of eligible articles, studies reporting on adults were included, due to the small number of headache-specific pediatric trials in complementary medicine. We refer to the existing pediatric articles in the particular sections.

The following search commands were applied: "CAMmethod" AND headache or migraine; Complementary medicine AND headache or migraine. The language filter was set to English and German publications. The identified titles and abstracts were reviewed for content and relevance to select those covering CAM aspects of pediatric headache.

In addition, checking the reference lists of the selected articles for pertinent articles and searching as well the CAMQUEST database, a European-wide search portal for CAM, completed the bibliography.

\section{Acupuncture}

Acupuncture is a fundamental component of traditional Chinese medicine, a technique used for about 3,000 years. ${ }^{11}$ Today, this technique is one of the most commonly used complementary therapies in many countries. ${ }^{12}$

Within the concept of traditional Chinese medicine, migraine is considered to be an internal disease, mostly interpreted as a disorder of the liver. According to traditional Chinese medicine, the goal of acupuncture is to restore a state of equilibrium by removing blockages in the flow of blood and $q i$. The mechanisms by which acupuncture should obtain an analgesic effect in headache treatment are not completely understood. However, some reports on experimental measurable and repeatable physiologic effects exist, and several hypotheses like an activation of nervous system structures in the control of pain perception ${ }^{13-15}$ and probable anti-inflammatory effects ${ }^{16-18}$ of acupuncture have been shown in experimental studies.

The available articles referring to acupuncture and headache treatment are very heterogenous. Several randomized controlled trials (RCTs) have been performed that examined the effect of acupuncture in chronic headache prophylaxis, using different acupuncture points and needles, electroacupuncture or laser acupuncture, and comparing with sham acupuncture (non-acupoints), to minimal acupuncture (needles inserted into non-acupoints and/or superficially) or a standard medicational therapy. Some studies sought to evaluate the use of acupuncture in acute migraine treatment.

Literature on acupuncture in children with headaches is still poor. One study ${ }^{19}$ examining 22 migraine patients aged 7 to 15 years and divided into two groups ("true" and "placebo" acupuncture) found a significant reduction in the frequency and intensity of the migraine attacks in the group with true acupuncture. Furthermore, they found a significant increase in $\beta$-endorphin levels in the plasma in the acupuncture group versus the placebo group. Another RCT study examining laser acupuncture in 43 children (mean age \pm SD, $12.3 \pm 2.6$ years) with headache ${ }^{20}$ showed a significant decrease of the mean number of headaches per month and significantly decreased headache severity and monthly hours with headache in the treatment group.

A Cochrane review was split into separate reviews on migraine $^{21}$ and tension-type headache. ${ }^{22}$ The migraine review included 22 trials with 4,419 participants. In five of the six trials that compared acupuncture with no prophylactic treatment or routine care only, the patients receiving acupuncture had higher response rates and fewer headaches after 3 to 4 months. Four trials compared acupuncture to proven prophylactic drug treatment. Overall, in these trials acupuncture was associated with slightly better outcomes and fewer adverse effects than prophylactic drug treatment (but not to sham intervention) regarding responder rate and attack frequency, although the small effect size might question the clinical relevance.

Whereas in this review true acupuncture intervention compared with sham interventions in 14 trials did not show a statistically significant superiority, a more recent meta-analysis ${ }^{23}$ on acupuncture for chronic pain did not only find acupuncture effective for the treatment of chronic pain but significant differences between true and sham acupuncture as well, which would indicate that acupuncture is more than a placebo.

The review on acupuncture in the treatment of tensiontype headache included 11 trials with 2,317 participants. Five of the six trials comparing acupuncture with a sham acupuncture intervention showed small but statistically significant benefits of acupuncture over sham. Three of the four trials comparing acupuncture with physiotherapy, massage, or relaxation techniques were difficult to interpret but on the whole suggested slightly better results for some outcomes in the control groups. ${ }^{22}$ The improvements were observed in all specified outcome measures as proportion of responders, number of headache days, headache intensity, frequency of use of analgesic agents, and headache scores. However, the clinical relevance of the improvements could not be concluded due to the small effect size.

The data on acupuncture in terminating a migraine attack are not easy to interpret. In one study ${ }^{24}$ acupuncture showed an effect superior to placebo in preventing a full attack, but sumatriptan provided a faster response and was more effective when used as a second intervention in patients who developed a full attack. In practicality, acupuncture on an emergency basis might not always be readily available. The studies addressing acupuncture in primary headache syndromes are summarized in - Table $\mathbf{1}$.

To summarize, acupuncture might provide a valuable nonpharmacologic tool within the multidisciplinary treatment of chronic headaches. However, acupuncture should only be practiced on patients who are old enough to cooperate, and further studies are needed to consolidate the promising suggestions for children under rigorous standards. These 
Table 1 Acupuncture

\begin{tabular}{|c|c|c|c|c|c|}
\hline $\begin{array}{l}\text { Study by } \\
\text { reference } \\
\text { no. }\end{array}$ & Population & Intervention & $\begin{array}{l}\text { Study } \\
\text { design }\end{array}$ & $\begin{array}{l}\text { Level of } \\
\text { evidence }\end{array}$ & Result \\
\hline 19 & Children & Acupuncture in migraine & OT & C & $\begin{array}{l}\text { Migraine frequency and intensity were } \\
\text { decreased significantly after true } \\
\text { acupuncture, whereas no significant } \\
\text { improvements were seen after placebo } \\
\text { acupuncture (though a } p \text { value was } \\
\text { not reported). }\end{array}$ \\
\hline 20 & Children & $\begin{array}{l}\text { Laser acupuncture in migraine } \\
\text { and tension-type headache }\end{array}$ & $\mathrm{RCT}$ & B & $\begin{array}{l}\text { Reduction of the mean number of } \\
\text { headaches per month }(p<0.001) \text {, } \\
\text { severity, and monthly hours when } \\
\text { compared with sham intervention. }\end{array}$ \\
\hline 21 & Mainly adults & Acupuncture in migraine & MA & A & $\begin{array}{l}\text { Benefit of treatment of acute migraine } \\
\text { attacks compared with routine care, } \\
\text { no evidence for an effect of acupuncture } \\
\text { over sham intervention. }\end{array}$ \\
\hline 22 & Mainly adults & $\begin{array}{l}\text { Acupuncture in tension-type } \\
\text { headache }\end{array}$ & MA & $A$ & $\begin{array}{l}\text { Benefit of treatment compared with } \\
\text { routine care, sham intervention, } \\
\text { and other therapies. }\end{array}$ \\
\hline 23 & All ages & Acupuncture in chronic pain & MA & $A$ & $\begin{array}{l}\text { Benefit of treatment compared with } \\
\text { sham intervention. }\end{array}$ \\
\hline 24 & Adults & $\begin{array}{l}\text { Sumatriptan or acupuncture in } \\
\text { preventing of acute migraine } \\
\text { attacks versus placebo }\end{array}$ & $\mathrm{RCT}$ & $\mathrm{B}$ & $\begin{array}{l}\text { Sumatriptan }(p<0.001) \text { and acupuncture } \\
(p=0.02) \text { were effective compared with } \\
\text { placebo in preventing an acute migraine } \\
\text { attack, whereas sumatriptan was shown } \\
\text { to act faster. }\end{array}$ \\
\hline
\end{tabular}

Note: Level A: two or more clinically controlled, randomized studies performed according to good clinical practice (GCP), versus placebo or versus active treatment of proven efficacy. Level B: one clinically controlled, randomized study performed according to GCP or more than one well-designed clinical case-control study or cohort study. Level C: favorable judgment of two thirds of the Ad Hoc Committee members, historical control subjects, nonrandomized studies, case reports.

Abbreviations: MA, meta-analysis; OT, open trial; RCT, randomized controlled trial.

standards could implicate carefully selected control interventions as sham acupuncture and/or established pharmacologic therapies with a sufficient sample size to show at least noninferiority.

\section{Homeopathy}

Homeopathy is a 250-year-old health care system, founded by Samuel Hahnemann, MD. It is one of the most frequently used $^{25}$ and widespread alternative therapies, especially common in Germany, France, the United Kingdom, North America, and India. Within the context of homeopathy, the proclaimed basis is the so-called principle of similarity, according to which a substance that causes the symptoms of a disease in healthy people will cure that disease in sick people. ${ }^{26} \mathrm{~A}$ further attribute is the use of minute doses, that is, logarithmic potencies with "dilutions" beyond any likelihood to contain even one molecule of the original substance over the $12 \mathrm{C}$ potency (corresponding to a dilution of $10^{-24}$ ). Interestingly, reports demonstrate that it is possible to determine the original substance in "ultra-high dilutions" 27 far beyond the $12 \mathrm{C}$ with special methods. The active principle of homeopathy is still not understood.

Recently, the first pediatric study on homeopathic treatment of headaches (migraines) has been published. This observational, prospective, noncomparative, multicenter study showed a significant decrease in the frequency, severity, and duration of migraine attacks and reduced absenteeism from school during 6 months of treatment. ${ }^{28}$ Within the last 20 years two observational headache studies have been published with adults patients ${ }^{29,30}$ and four RCT headache studies with adults patients. ${ }^{31-34}$ The observational studies showed significant improvements of the homeopathically treated patients, the second one likewise a marked decrease of the use of conventional treatment and health services. Three of the four RCTs showed no significant benefit over placebo for homoeopathic treatment, ${ }^{31,32,34}$ whereas one showed statistically significant reduction in attack frequency in the homeopathy group and statistically not significant trends in favor of homeopathy for pain intensity and overall evaluation. ${ }^{33}$

The positive observational studies do not answer the question as to whether the positive effects of the homeopathic therapy are treatment specific or not. Although some homeopathic RCTs on other pediatric diseases, such as attention deficit hyperactivity disorder ${ }^{35}$ and childhood diarrhea, ${ }^{36}$ demonstrated treatment-specific effects of homeopathy, evidence-based proof of the effectiveness of homeopathic treatment has not been found. Furthermore, 
RCT studies are required to verify possible benefits of homeopathic treatment in childhood headache and to determine the role of homeopathy in the multidisciplinary pediatric headache treatment. The studies addressing homeopathy in primary headache syndromes are summarized in - Table 2.

\section{Nutritional Supplements}

Magnesium seems to play an important role in migraine pathogenesis. Deficiency in magnesium has been associated with cortical spreading depression, ${ }^{37}$ platelet aggregation, ${ }^{38}$ vasoconstriction, ${ }^{39}$ and neurotransmitter release. ${ }^{40}$

The data on magnesium in the prophylactic treatment for children are rare. One $\mathrm{RCT}^{41}$ was conducted to examine the prophylactic effect of oral magnesium oxide on migrainous headache in children and adolescents. This study did not unequivocally determine whether oral magnesium oxide is or is not overall superior to placebo in preventing frequent migrainous headache in children even if it showed a significant reduction in headache days.

Magnesium deficiency has been shown to be common in women with menstrual-related migraine, ${ }^{42}$ and magnesium supplementation from ovulation to the first day of flow has resulted in a significant reduction of the number of days with headache and of pain intensity compared with placebo. ${ }^{43}$
Also, in gender-mixed RCTs magnesium (di-)citrate supplementation showed a significant prophylactic effect in patients with migraine without aura. Active treatment resulted in a significant decrease in attack frequency and severity. ${ }^{44,45}$

The most common adverse effect associated with oral magnesium supplementation is diarrhea. Diarrhea seems to increase in the use of poorly absorbed magnesium salts as seen in a further RCT where almost half of the patients in the treatment group developed diarrhea and no effect on the migraine was seen. ${ }^{46}$

Special caution is necessary in patients with kidney disease, due to the renal excretion of magnesium and an increased risk of magnesium toxicity (loss of deep tendon reflexes followed by muscle weakness, respiratory paralysis, and death) in patients with renal function impairment. Intravenous magnesium supplementation $(1 \mathrm{~g})$ has not been shown to be more effective than placebo in aborting migraine attacks. ${ }^{47}$

Other migraine-influencing supplements are vitamin B2 (riboflavin) and coenzyme Q10, which play a role in mitochondrial function, which has been speculated to have a part in migraine pathology. ${ }^{48,49}$ Riboflavin was shown to lead possibly to a significant reduction of migraine attacks in adults, ${ }^{50}$ whereas RCTs in children have not confirmed this

Table 2 Homeopathy

\begin{tabular}{|c|c|c|c|c|c|}
\hline $\begin{array}{l}\text { Study by } \\
\text { reference } \\
\text { no. }\end{array}$ & Population & Intervention & $\begin{array}{l}\text { Study } \\
\text { design }\end{array}$ & $\begin{array}{l}\text { Level of } \\
\text { evidence }\end{array}$ & Result \\
\hline 28 & Children & $\begin{array}{l}\text { Individualized homeopathic } \\
\text { prescriptions in migraine }\end{array}$ & OT & C & $\begin{array}{l}\text { Decrease of frequency, severity, and duration } \\
\text { of migraine attacks (all } p<0.001) \\
\text { children spent less time off school } \\
(p<0.001) \text {. }\end{array}$ \\
\hline 29 & Adults & $\begin{array}{l}\text { Individualized homeopathic } \\
\text { prescriptions in migraine } \\
\text { and tension-type headache }\end{array}$ & OT & C & $\begin{array}{l}\text { Improvement in pain and the limitations } \\
\text { caused by pain in }>60 \% \text { of patients, all the } \\
\text { differences between pre- and posttreatment } \\
\text { were statistically significant, with the } \\
\text { strongest results in the "bodily pain" and } \\
\text { "vitality" parameters }(p<0.0001) \text {. }\end{array}$ \\
\hline 30 & Adults & $\begin{array}{l}\text { Individualized homeopathic } \\
\text { prescriptions in migraine }\end{array}$ & OT & C & $\begin{array}{l}\text { Reduction of migraine severity, improvement } \\
\text { of quality of life, decrease of use of } \\
\text { conventional treatment and health services } \\
(p<0.001) \text {. }\end{array}$ \\
\hline 31 & Adults & $\begin{array}{l}\text { Individualized homeopathic } \\
\text { prescriptions in migraine and } \\
\text { tension-type headache }\end{array}$ & RCT & $B$ & $\begin{array}{l}\text { No significant difference in any parameter } \\
\text { between homeopathy and placebo (frequency, } \\
\text { use of medication for acute headache). }\end{array}$ \\
\hline 32 & Adults & $\begin{array}{l}\text { Individualized homeopathic } \\
\text { prescriptions in migraine }\end{array}$ & RCT & $B$ & $\begin{array}{l}\text { No significant benefit over placebo of } \\
\text { homoeopathic treatment in attack frequency. }\end{array}$ \\
\hline 33 & Adults & $\begin{array}{l}\text { Homeopathic prescriptions } \\
\text { individualized for each } \\
\text { patient in migraine }\end{array}$ & RCT & B & $\begin{array}{l}\text { No significant benefit with respect to } \\
\text { frequency (diary), pain intensity, and drug } \\
\text { consumption of homoeopathic compared } \\
\text { with placebo, but statistically significant } \\
\text { reduction in attack frequency } \\
\text { (neurologists' trial evaluation) in the } \\
\text { homeopathy group ( } p=0.04) \text {. }\end{array}$ \\
\hline
\end{tabular}

Note: Level B: one clinically controlled, randomized study performed according to good clinical practice or more than one well-designed clinical casecontrol study or cohort study. Level C: favorable judgment of two thirds of the Ad Hoc Committee members, historical control subjects, nonrandomized studies, case reports.

Abbreviations: OT, open trial; RCT, randomized controlled trial. 
finding. ${ }^{51,52}$ However, there is some evidence for a reduction of mean frequency of headaches with a tension-type phenotype in favor of the riboflavin treatment. ${ }^{52}$ Few pediatric patients had vomiting or increased appetite, respectively, most likely for causes unrelated to the use of riboflavin. ${ }^{53}$

There seemed to be evidence for a special effectiveness of coenzyme Q10 in the prophylaxis of pediatric migraine as a study $^{54}$ of 1,550 pediatric patients with frequent headaches measured coenzyme Q10 levels below the reference range in nearly one third of the subjects and found a significant reduction of headache frequency with rising coenzyme Q10 levels under coenzyme Q10 supplementation. In contrast to these findings, a more recent $\mathrm{RCT}^{55}$ showed no difference in headache outcomes between coenzyme Q10 supplementation and placebo groups at the end of the observation period (32 weeks), only a significant improvement in weeks 1 to 4 , which might suggest an earlier improvement in headache severity under coenzyme Q10 supplementation.

These dietary supplements are suitable for less severe migraines, as when beginning prophylactic therapy to avoid side effects of more evident medication or as one component of a multidisciplinary individual treatment. Preparations combining magnesium, vitamin B2, and coenzyme Q10 are available but expensive, and their efficacy not well proven. The decision whether to use these preparations or cheaper magnesium preparations alone must be made individually. The studies addressing nutritional supplements in primary headache syndromes are summarized in - Table 3.

\section{Herbal Preparations}

Butterbur (Petasites hybridus) is a perennial shrub found throughout Europe and parts of Asia. It has been used traditionally as a remedy for pain, fever, spasms, and wound healing. The mode of action of this plant is not fully understood yet, but it is supposed to act through calcium channel regulation and inhibition of peptide leukotriene biosynthesis, thus influencing the inflammatory cascade associated with migraine. ${ }^{56}$ The efficacy of $P$. hybridus in migraine prevention has been evaluated in numerous adult studies. In two studies in children (one an RCT), it was shown to be well tolerated and superior to placebo effect. ${ }^{57,58}$

The butterbur plant is known to contain as well hepatotoxic and carcinogenic pyrrolizidine alkaloids. These substances are removed in commercially available preparations. Patients should be advised to use only certified and pyrrolizidine alkaloid-free products. The most frequently reported adverse events were mild gastrointestinal symptoms like eructation. For safety reasons a check of the aminotransferases after the first month of intake is recommended. In clinical practice the available products in Europe are considered safe, and increase of liver enzyme is rare.

Feverfew (Tanacetum parthenium) is a perennial herb that grows into a small bush originally native to the Balkan Mountains but now growing throughout Europe, North America, and South America. Traditionally, it is used in the treatment of fevers, headache, infertility, toothaches, inflammation, and arthritis. Its antimigraine action is credited to the partenolides within the leaves. It may act in migraine pro- phylaxis by inhibiting platelet aggregation and the release of serotonin from platelets and white blood cells. It may also act as an anti-inflammatory agent through the inhibition of prostaglandin synthesis and phospholipase A. ${ }^{59-62}$ The contradictory results of many RCTs for the efficacy of feverfew in migraine were attributed to wide variations in the strength of the partenolides ${ }^{63}$ and differences in the stability of feverfew preparations. ${ }^{64}$ Subsequently, a more stable feverfew extract (MIG-99) was created. A double-blind, placebo-controlled study that used the standardized extract in 170 patients showed a significant improvement under therapy with $6.25 \mathrm{mg}$ feverfew $\mathrm{CO}_{2}$ extract (MIG-99) three times a day in adults. ${ }^{65}$ Examinations in pediatric patients are still to be done. No major safety or tolerability issues have been reported, although side effects in the RCTs included gastrointestinal disturbances, mouth ulcers, and a "post-feverfew syndrome" of joint aches. Pregnant women should not use feverfew because it may cause uterine contractions, resulting in miscarriage or preterm labor. It can also cause allergic reactions. Patients with allergies to other members of the daisy family, including ragweed and chrysanthemums, are more likely to be allergic to feverfew. Studies addressing herbal preparations in primary headache syndromes are summarized in - Table 4.

\section{Manual Therapies and Osteopathy/Osteopathic Medicine}

The definitions of osteopathic medicine are quite varied. ${ }^{66}$ Thus, the few articles dealing with this matter are not easy to compare. The only RCT on manual therapy in children and adolescents with suspected cervicogenic headache failed to show efficacy. ${ }^{67}$ Studies on osteopathic treatment in pediatric patients with primary headache syndromes are still missing.

A systematic review of RCTs of CAM in the treatment of tension-type and cervicogenic headache from $1999^{68}$ indicated from a subset of high-quality studies that some CAM therapies may be useful in the treatment of these common forms of headache. One of the adult studies, ${ }^{69}$ a prospective, randomized, parallel-group comparison of amitriptyline, spinal manipulation, and their combination, failed to show an advantage of combining amitriptyline and spinal manipulation for the treatment of migraine headache. However, clinically important improvement was observed in all three study groups over time. The reduction of headache intensity reached $49 \%$ for amitriptyline, $40 \%$ for spinal manipulation, and $41 \%$ for their combination. During the posttreatment follow-up period, the reduction from baseline was reported to be $24 \%$ for amitriptyline, $42 \%$ for spinal manipulation, and $25 \%$ for their combination ( $p=0.05$ ). Overall, spinal manipulation seemed to be as effective in this study as a wellestablished and efficacious pharmacologic treatment. The studies addressing manual therapies in primary headache syndromes are summarized in - Table 5 .

\section{Discussion}

Biobehavioral therapy, covering relaxation techniques, biofeedback treatment, operant pain treatment, pain coping, 
Table 3 Nutritional supplements

\begin{tabular}{|c|c|c|c|c|c|}
\hline $\begin{array}{l}\text { Study by } \\
\text { reference } \\
\text { no. }\end{array}$ & Population & Intervention & $\begin{array}{l}\text { Study } \\
\text { design }\end{array}$ & $\begin{array}{l}\text { Level of } \\
\text { evidence }\end{array}$ & Result \\
\hline 41 & Children & $\begin{array}{l}\text { Magnesium versus placebo } \\
\text { in migraine }\end{array}$ & $\mathrm{RCT}$ & B & $\begin{array}{l}\text { Decrease over time in headache frequency in the } \\
\text { magnesium oxide group }(p=0.0037) \text { but not in } \\
\text { the placebo group }(p=0.086) \text {, although the } \\
\text { slopes of these two lines were not statistically } \\
\text { significantly different from each other } \\
(p=0.88) \text {; the group treated with magnesium } \\
\text { oxide had significantly lower headache severity } \\
(p=0.0029) \text { relative to the placebo group. }\end{array}$ \\
\hline 44 & Adults & $\begin{array}{l}\text { Magnesium versus placebo } \\
\text { in migraine }\end{array}$ & $\mathrm{RCT}$ & B & $\begin{array}{l}\text { Reduction of attack frequency and drug con- } \\
\text { sumption for symptomatic treatment per pa- } \\
\text { tient significantly higher in patients treated with } \\
\text { magnesium }(p<0.05) \text {. }\end{array}$ \\
\hline 45 & Adults & $\begin{array}{l}\text { Magnesium versus placebo } \\
\text { in migraine }\end{array}$ & RCT & $B$ & $\begin{array}{l}\text { Reduction of attack frequency }(p=0.005) \text {, } \\
\text { attack severity }(p<0.001) \text {, and } \mathrm{P} 1 \text { amplitude } \\
(p<0.05) \text { in favor magnesium treatment versus } \\
\text { placebo. }\end{array}$ \\
\hline 46 & Adults & $\begin{array}{l}\text { Magnesium versus placebo } \\
\text { in migraine }\end{array}$ & $\mathrm{RCT}$ & B & $\begin{array}{l}\text { No statistically significant differences in } \\
\text { reduction of attack frequency and severity } \\
\text { between magnesium and placebo. }\end{array}$ \\
\hline 47 & Adults & $\begin{array}{l}\text { Intravenous magnesium } \\
\text { versus metoclopramide or } \\
\text { placebo in acute migraine } \\
\text { attacks }\end{array}$ & RCT & $B$ & $\begin{array}{l}\text { No significant differences of attack termination } \\
\text { of magnesium compared with placebo. }\end{array}$ \\
\hline 51 & Children & $\begin{array}{l}\text { High-dose riboflavin versus } \\
\text { placebo in migraine } \\
\text { prophylaxis }\end{array}$ & RCT & B & $\begin{array}{l}\text { Riboflavin was not superior to placebo in } \\
\text { reducing attack frequency. }\end{array}$ \\
\hline 52 & Children & $\begin{array}{l}\text { Medium-dose riboflavin } \\
\text { versus placebo in migraine } \\
\text { prophylaxis }\end{array}$ & RCT & B & $\begin{array}{l}\text { Riboflavin was not superior to placebo in } \\
\text { reducing migraine attack frequency but in } \\
\text { reducing attack frequency of headaches with } \\
\text { a tension-type phenotype }(p=0.04) \text {. }\end{array}$ \\
\hline 53 & Children & $\begin{array}{l}\text { Riboflavin in migraine } \\
\text { prophylaxis }\end{array}$ & OT & $C$ & $\begin{array}{l}\text { Attack frequency reduced significantly } \\
(p<0.01) \text {. }\end{array}$ \\
\hline 50 & Adults & $\begin{array}{l}\text { High-dose riboflavin versus } \\
\text { placebo in migraine } \\
\text { prophylaxis }\end{array}$ & RCT & B & $\begin{array}{l}\text { Riboflavin was superior to placebo in reducing } \\
\text { attack frequency }(p=0.005) \text { and headache days } \\
(p=0.012)\end{array}$ \\
\hline 54 & Children & $\begin{array}{l}\text { Coenzyme Q10 in } \\
\text { migraine prophylaxis }\end{array}$ & OT & $C$ & $\begin{array}{l}\text { Improvement of headache frequency } \\
(p<0.001) \text { and headache disability assessed } \\
\text { with PedMIDAS }(p<0.001) \text {. }\end{array}$ \\
\hline 55 & Children & $\begin{array}{l}\text { Coenzyme Q10 compared } \\
\text { with placebo in migraine } \\
\text { prophylaxis }\end{array}$ & RCT & $B$ & $\begin{array}{l}\text { Coenzyme Q10 was not superior to placebo in } \\
\text { reducing migraine attack frequency, severity, } \\
\text { and duration. }\end{array}$ \\
\hline
\end{tabular}

Note: Level B: one clinically controlled, randomized study performed according to good clinical practice or more than one well-designed clinical casecontrol study or cohort study. Level C: favorable judgment of two thirds of the Ad Hoc Committee members, historical control subjects, nonrandomized studies, case reports.

Abbreviations: PedMIDAS, Pediatric Migraine Disability Assessment Score; OT, open trial; RCT, randomized controlled trial.

cognitive-behavioral, and multimodal treatment, is the approach of first choice in the prophylactic treatment of primary pediatric headache disorders. Nevertheless, CAM therapies play an increasing role in the multidisciplinary treatment of headaches in childhood and adolescence. Every headache patient needs to have a personalized and tailored program of education, psychological strategies, pharmacotherapy, and, as one further option, complementary medicine. The question of the most appropriate individualized therapy needs to be answered undogmatically and without deciding strictly between conventional or complementary medicine. CAM may have promising perspectives especially in headache prevention, whereas in acute attacks, demanding a rapid and secure therapeutic approach, conventional medicinal options are still favored.

In assessing the possible benefit of CAM methods, we have to keep in mind their wide heterogeneity. In homeopathy and osteopathic medicine, only a few trials on pediatric headache therapy have been performed. Thus, even if these methods 
Table 4 Herbal preparations

\begin{tabular}{|l|l|l|l|l|l|}
\hline $\begin{array}{l}\text { Study by } \\
\text { reference } \\
\text { no. }\end{array}$ & Population & Intervention & $\begin{array}{l}\text { Study } \\
\text { design }\end{array}$ & $\begin{array}{l}\text { Level of } \\
\text { evidence }\end{array}$ & Result \\
\hline 57 & Children & $\begin{array}{l}\text { Butterbur root extract in } \\
\text { migraine compared with } \\
\text { placebo }\end{array}$ & RCT & B & $\begin{array}{l}\text { Butterbur was superior to placebo in reducing } \\
\text { attack frequency during the follow-up period but } \\
\text { not during the study period }(p=0.044) .\end{array}$ \\
\hline 58 & Children & $\begin{array}{l}\text { Butterbur root extract in } \\
\text { migraine }\end{array}$ & OT & C & $\begin{array}{l}\text { Seventy-seven percent of all patients reported a } \\
\text { reduction in attack frequency of migraine at- } \\
\text { tacks of at least 50\%. }\end{array}$ \\
\hline 65 & Adults & $\begin{array}{l}\text { Feverfew } \mathrm{CO}_{2} \text { extract } \\
\text { (MIG-99) in migraine } \\
\text { compared with placebo }\end{array}$ & RCT & B & $\begin{array}{l}\text { MIG-99 was superior to placebo in reducing } \\
\text { attack frequency }(p=0.0049) .\end{array}$ \\
\hline
\end{tabular}

Note: Level B: one clinically controlled, randomized study performed according to good clinical practice or more than one well-designed clinical case-control study or cohort study. Level C: favorable judgment of two thirds of the Ad Hoc Committee members, historical control subjects, nonrandomized studies, case reports.

Abbreviations: OT, open trial; RCT, randomized controlled trial.

Table 5 Manual therapies and osteopathy and osteopathic medicine

\begin{tabular}{|c|c|c|c|c|c|}
\hline $\begin{array}{l}\text { Study by } \\
\text { reference } \\
\text { no. }\end{array}$ & Population & Intervention & $\begin{array}{l}\text { Study } \\
\text { design }\end{array}$ & $\begin{array}{l}\text { Level of } \\
\text { evidence }\end{array}$ & Result \\
\hline 67 & Children & $\begin{array}{l}\text { Manual therapy in children } \\
\text { and adolescents with } \\
\text { cervicogenic headache } \\
\text { compared with placebo }\end{array}$ & $\mathrm{RCT}$ & B & $\begin{array}{l}\text { Manual therapy was not superior compared with } \\
\text { placebo with respect to percentage of days with } \\
\text { headache, total duration of headache, days with } \\
\text { school absence due to headache, consume of } \\
\text { analgesics, and intensity of headache. }\end{array}$ \\
\hline 68 & Adults & $\begin{array}{l}\text { Spinal manipulation, } \\
\text { amitriptyline, and the } \\
\text { combination of both } \\
\text { therapies in migraine }\end{array}$ & OT & C & $\begin{array}{l}\text { Reduction in headache index scores during } \\
\text { treatment compared with baseline was } 49 \% \text { for } \\
\text { amitriptyline, } 40 \% \text { for spinal manipulation, and } \\
41 \% \text { for the combined group, revealing the } \\
\text { statistical differences between the treatment } \\
\text { groups. }\end{array}$ \\
\hline 69 & Adults & $\begin{array}{l}\text { Systematic review of } \\
\text { randomized clinical trials } \\
\text { of CAM in the treatment of } \\
\text { tension-type and } \\
\text { cervicogenic headache }\end{array}$ & SR & B & $\begin{array}{l}\text { Evidence from a subset of high-quality studies } \\
\text { indicates that some CAM therapies may be } \\
\text { useful in the treatment of these common forms } \\
\text { of headache. }\end{array}$ \\
\hline
\end{tabular}

Note: Level B: one clinically controlled, randomized study performed according to good clinical practice or more than one well-designed clinical casecontrol study or cohort study. Level C: favorable judgment of two thirds of the Ad Hoc Committee members, historical control subjects, nonrandomized studies, case reports.

Abbreviations: OT, open trial; RCT, randomized controlled trial; SR, systematic review.

turned out to be a valid option, it remains questionable which variation of the method would be the most effective. In contrast for acupuncture, more evidence demonstrating its considerable role in headache prophylaxis is available. Research on acupuncture may soon reveal which treatment model proves to be the best within the method.

Further research is necessary using more rigorous and systematic methodology. Studies addressing established pharmacologic therapies of headaches in children are more prevalent than studies using CAM, suggesting a higher level of evidence. However, comparison of both methods is difficult because studies matching established pharmacologic treatments versus CAM within two therapy groups are lacking. ${ }^{10}$ The limited evidence of CAM therapy in pediatric headache is also in part caused by methodologic problems. Placebo effects in children are much more powerful than in adults; therefore, it is difficult to show superiority of outcomes within treatment groups compared with control groups because both are treatment. In addition, beliefs, concepts, wishes, and concerns of patients and their parents show important influence on treatment acceptance.

\section{References}

1 Ottolini MC, Hamburger EK, Loprieato JO, et al. Complementary and alternative medicine use among children in the Washington, DC area. Ambul Pediatr 2001;1(2):122-125

2 Smith C, Eckert K. Prevalence of complementary and alternative medicine and use among children in South Australia. J Paediatr Child Health 2006;42(9):538-543 
3 Shenfield G, Lim E, Allen H. Survey of the use of complementary medicines and therapies in children with asthma. J Paediatr Child Health 2002;38(3):252-257

4 Gaul C, Eismann R, Schmidt T, et al. Use of complementary and alternative medicine in patients suffering from primary headache disorders. Cephalalgia 2009;29(10):1069-1078

5 Weissenstein A, Straeter A, Villalon G, Luchter E, Bittmann S. High frequency of CAM use among children in Germany. J Altern Complement Med 2012;18(8):729-730

6 Ernst ERK, Mills S, Hill R, Mitchell A, Willoughby M, White A. Complementary medicine-a definition. Br J Gen Pract 1995;45 (398):506

7 (NCCAM) NCfCaAM. What is complementary and alternative medicine (CAM)? NCCAM Publication No D347. Available at: http://nccam.nih.gov/health/whatiscam; 2010

8 Eisenberg DM, Davis RB, Ettner SL, et al. Trends in alternative medicine use in the United States, 1990-1997: results of a followup national survey. JAMA 1998;280(18):1569-1575

9 Häußermann D. Allensbach-Studie: Wachsendes Vertrauen in Naturheilmittel. Deutsches Ärzteblatt 1997;94(39):A2466-A2467

10 Termine C, Ozge A, Antonaci F, Natriashvili S, Guidetti V, WöberBingöl C. Overview of diagnosis and management of paediatric headache. Part II. Therapeutic management. J Headache Pain 2011;12(1):25-34

11 Cheng X. Chinese Acupuncture and Moxibustion. Beijing: Foreign Languages Press; 1987

12 Bodeker G, Ong C, Grundy C, Burford G, Shein K. WHO Global Atlas of Traditional, Complementary and Alternative Medicine. Kobe: WHO Center for Health Development; 2005

13 Pomeranz B, Cheng R, Law P. Acupuncture reduces electrophysiological and behavioral responses to noxious stimuli: pituitary is implicated. Exp Neurol 1977;54(1):172-178

14 Takeshige C, Kobori M, Hishida F, Luo CP, Usami S. Analgesia inhibitory system involvement in nonacupuncture point-stimulation-produced analgesia. Brain Res Bull 1992;28(3):379-391

15 Takeshige C, Zhao WH, Guo SY. Convergence from the preoptic area and arcuate nucleus to the median eminence in acupuncture and nonacupuncture point stimulation analgesia. Brain Res Bull 1991; 26(5):771-778

16 Lao L, Zhang RX, Zhang G, Wang X, Berman BM, Ren K. A parametric study of electroacupuncture on persistent hyperalgesia and Fos protein expression in rats. Brain Res 2004;1020(1-2): $18-29$

17 Ceccherelli F, Gagliardi G, Ruzzante L, Giron G. Acupuncture modulation of capsaicin-induced inflammation: effect of intraperitoneal and local administration of naloxone in rats. A blinded controlled study. J Altern Complement Med 2002;8(3):341-349

18 Jeong HJ, Hong SH, Nam YC, et al. The effect of acupuncture on proinflammatory cytokine production in patients with chronic headache: a preliminary report. Am J Chin Med 2003;31(6): 945-954

19 Pintov S, Lahat E, Alstein M, Vogel Z, Barg J. Acupuncture and the opioid system: implications in management of migraine. Pediatr Neurol 1997;17(2):129-133

20 Gottschling S, Meyer S, Gribova I, et al. Laser acupuncture in children with headache: a double-blind, randomized, bicenter, placebo-controlled trial. Pain 2008;137(2):405-412

21 Linde K, Allais G, Brinkhaus B, Manheimer E, Vickers A, White AR. Acupuncture for migraine prophylaxis. Cochrane Database Syst Rev 2009;(1):CD001218

22 Linde K, Allais G, Brinkhaus B, Manheimer E, Vickers A, White AR. Acupuncture for tension-type headache. Cochrane Database Syst Rev 2009;(1):CD007587

23 Vickers AJ, Cronin AM, Maschino AC, et al; for the Acupuncture Trialists' Collaboration. Acupuncture for chronic pain: individual patient data meta-analysis. Arch Intern Med 2012;172(19): 1444-1453
24 Melchart D, Thormaehlen J, Hager S, Liao J, Linde K, Weidenhammer W. Acupuncture versus placebo versus sumatriptan for early treatment of migraine attacks: a randomized controlled trial. J Intern Med 2003;253(2):181-188

25 Gottschling S, Gronwald B, Schmitt S, et al. Use of complementary and alternative medicine in healthy children and children with chronic medical conditions in Germany [published online ahead of print July 11, 2011]. Complement Ther Med doi: 10.1016/ j.ctim.2011.06.001

26 Hahnemann S. Organon der Heilkunst. Volume 6. Heidelberg, Germany: Huaug Verlag; 1999

27 Rey L. Can low-temperature thermoluminescence cast light on the nature of ultra-high dilutions? Homeopathy 2007;96(3):170-174

28 Danno K, Colas A, Masson JL, Bordet MF. Homeopathic treatment of migraine in children: results of a prospective, multicenter, observational study. J Altern Complement Med 2012

29 Muscari-Tomaioli G, Allegri F, Miali E, et al. Observational study of quality of life in patients with headache, receiving homeopathic treatment. Br Homeopath J 2001;90(4):189-197

30 Witt CM, Lüdtke R, Willich SN. Homeopathic treatment of patients with migraine: a prospective observational study with a 2-year follow-up period. J Altern Complement Med 2010;16(4):347355

31 Walach H, Haeusler W, Lowes T, et al. Classical homeopathic treatment of chronic headaches. Cephalalgia 1997;17(2):119126, discussion 101

32 Whitmarsh TE, Coleston-Shields DM, Steiner TJ. Double-blind randomized placebo-controlled study of homoeopathic prophylaxis of migraine. Cephalalgia 1997;17(5):600-604

33 Straumsheim P, Borchgrevink C, Mowinckel P, Kierulf H, Hafslund O. Homeopathic treatment of migraine: a double blind, placebo controlled trial of 68 patients [see comment]. [see comment] $\mathrm{Br}$ Homeopath J 2000;89(1):4-7

34 Walach H, Lowes T, Mussbach D, et al. The long-term effects of homeopathic treatment of chronic headaches: one year follow-up and single case time series analysis. Br Homeopath J 2001;90 (2):63-72

35 Frei H, Everts R, von Ammon K, et al. Randomised controlled trials of homeopathy in hyperactive children: treatment procedure leads to an unconventional study design. Experience with openlabel homeopathic treatment preceding the Swiss ADHD placebo controlled, randomised, double-blind, cross-over trial. Homeopathy 2007;96(1):35-41

36 Jacobs J, Jonas WB, Jiménez-Pérez $\mathrm{M}$, Crothers D. Homeopathy for childhood diarrhea: combined results and metaanalysis from three randomized, controlled clinical trials. Pediatr Infect Dis J 2003;22(3):229-234

37 Mody I, Lambert JD, Heinemann U. Low extracellular magnesium induces epileptiform activity and spreading depression in rat hippocampal slices. J Neurophysiol 1987;57(3):869-888

38 Baudouin-Legros M, Dard B, Guicheney P. Hyperreactivity of platelets from spontaneously hypertensive rats. Role of external magnesium. Hypertension 1986;8(8):694-699

39 Altura BT, Memon ZI, Zhang A, et al. Low levels of serum ionized magnesium are found in patients early after stroke which result in rapid elevation in cytosolic free calcium and spasm in cerebral vascular muscle cells. Neurosci Lett 1997;230(1):37-40

40 Coan EJ, Collingridge GL. Magnesium ions block an N-methyl-Daspartate receptor-mediated component of synaptic transmission in rat hippocampus. Neurosci Lett 1985;53(1):21-26

41 Wang F, Van Den Eeden SK, Ackerson LM, Salk SE, Reince RH, Elin RJ. Oral magnesium oxide prophylaxis of frequent migrainous headache in children: a randomized, double-blind, placebo-controlled trial. Headache 2003;43(6):601-610

42 Mauskop A, Altura BT, Altura BM. Serum ionized magnesium levels and serum ionized calcium/ionized magnesium ratios in women with menstrual migraine. Headache 2002;42(4):242-248 
43 Facchinetti F, Sances G, Borella P, Genazzani AR, Nappi G. Magnesium prophylaxis of menstrual migraine: effects on intracellular magnesium. Headache 1991;31(5):298-301

44 Peikert A, Wilimzig C, Köhne-Volland R. Prophylaxis of migraine with oral magnesium: results from a prospective, multi-center, placebo-controlled and double-blind randomized study. Cephalalgia 1996;16(4):257-263

45 Köseoglu E, Talaslioglu A, Gönül AS, Kula M. The effects of magnesium prophylaxis in migraine without aura. Magnes Res 2008;21(2):101-108

46 Pfaffenrath V, Wessely P, Meyer C, et al. Magnesium in the prophylaxis of migraine-a double-blind placebo-controlled study. Cephalalgia 1996;16(6):436-440

47 Cete Y, Dora B, Ertan C, Ozdemir C, Oktay C. A randomized prospective placebo-controlled study of intravenous magnesium sulphate vs. metoclopramide in the management of acute migraine attacks in the Emergency Department. Cephalalgia 2005;25 (3):199-204

48 Koo B, Becker LE, Chuang S, et al. Mitochondrial encephalomyopathy, lactic acidosis, stroke-like episodes (MELAS): clinical, radiological, pathological, and genetic observations. Ann Neurol 1993;34(1):25-32

49 Lantéri-Minet M, Desnuelle C. [Migraine and mitochondrial dysfunction]. Rev Neurol (Paris) 1996;152(4):234-238

50 Schoenen J, Jacquy J, Lenaerts M. Effectiveness of high-dose riboflavin in migraine prophylaxis. A randomized controlled trial. Neurology 1998;50(2):466-470

51 MacLennan SC, Wade FM, Forrest KM, Ratanayake PD, Fagan E, Antony J. High-dose riboflavin for migraine prophylaxis in children: a double-blind, randomized, placebo-controlled trial. J Child Neurol 2008;23(11):1300-1304

52 Bruijn J, Duivenvoorden H, Passchier J, Locher H, Dijkstra N, Arts WF. Medium-dose riboflavin as a prophylactic agent in children with migraine: a preliminary placebo-controlled, randomised, double-blind, cross-over trial. Cephalalgia 2010;30(12):14261434

53 Condò M, Posar A, Arbizzani A, Parmeggiani A. Riboflavin prophylaxis in pediatric and adolescent migraine. J Headache Pain 2009;10(5):361-365

54 Hershey AD, Powers SW, Vockell AL, et al. Coenzyme Q10 deficiency and response to supplementation in pediatric and adolescent migraine. Headache 2007;47(1):73-80

55 Slater SK, Nelson TD, Kabbouche MA, et al. A randomized, doubleblinded, placebo-controlled, crossover, add-on study of coenzyme Q10 in the prevention of pediatric and adolescent migraine. Cephalalgia 2011;31(8):897-905
56 Eaton J. Butterbur, herbal help for migraine. Nat Pharm 1998;2: 23-24

57 Oelkers-Ax R, Leins A, Parzer P, et al. Butterbur root extract and music therapy in the prevention of childhood migraine: an explorative study. Eur J Pain 2008;12(3):301-313

58 Pothmann R, Danesch U. Migraine prevention in children and adolescents: results of an open study with a special butterbur root extract. Headache 2005;45(3):196-203

59 Heptinstall S, White A, Williamson L, Mitchell JR. Extracts of feverfew inhibit granule secretion in blood platelets and polymorphonuclear leucocytes. Lancet 1985;1(8437):1071-1074

60 Heptinstall S, Groenewegen WA, Spangenberg P, Loesche W. Extracts of feverfew may inhibit platelet behaviour via neutralization of sulphydryl groups. J Pharm Pharmacol 1987;39(6):459-465

61 Pugh WJ, Sambo K. Prostaglandin synthetase inhibitors in feverfew. J Pharm Pharmacol 1988;40(10):743-745

62 Makheja AN, Bailey JM. A platelet phospholipase inhibitor from the medicinal herb feverfew (Tanacetum parthenium). Prostaglandins Leukot Med 1982;8(6):653-660

63 Draves A, Walker S. Parthenolide content of Canadian commercial feverfew preparations: label claims are misleading in most cases. Can Pharm J 2003;136:23-30 (RPC)

64 Willigmann I, Freudenstein J. Production of a Stable Feverfew (Tanacetum parthenium) Extract as an Active Substance for a Pharmaceutical Product. Vienna: Society for Medicinal Plant Research; 1998

65 Diener HC, Pfaffenrath V, Schnitker J, Friede M, Henneicke-von Zepelin $\mathrm{HH}$. Efficacy and safety of $6.25 \mathrm{mg}$ t.i.d. feverfew $\mathrm{CO} 2-$ extract (MIG-99) in migraine prevention-a randomized, doubleblind, multicentre, placebo-controlled study. Cephalalgia 2005;25 (11):1031-1041

66 Beyer WF. Kopfschmerz-was ist osteopathische Medizin? Manuelle Medizin 2001;39:301-303

67 Borusiak P, Biedermann H, Bosserhoff S, Opp J. Lack of efficacy of manual therapy in children and adolescents with suspected cervicogenic headache: results of a prospective, randomized, placebo-controlled, and blinded trial. Headache 2010;50 (2):224-230

68 Vernon H, McDermaid CS, Hagino C. Systematic review of randomized clinical trials of complementary/alternative therapies in the treatment of tension-type and cervicogenic headache. Complement Ther Med 1999;7(3):142-155

69 Nelson CF, Bronfort G, Evans R, Boline P, Goldsmith C, Anderson AV. The efficacy of spinal manipulation, amitriptyline and the combination of both therapies for the prophylaxis of migraine headache. J Manipulative Physiol Ther 1998;21(8):511-519 